\title{
Cenas E Tempos de Uma InfÂncia Sem Fim: o SENTIMENTo Trágico EM
}

\author{
INCÊNDIOS
}

\author{
Sandra Mara Corazza ${ }^{1}$ \\ Universidade Federal do Rio Grande do Sul, Brasil \\ Deniz Alcione Nicolay ${ }^{2}$ \\ Universidade Federal da Fronteira Sul, Brasil
}

\begin{abstract}
Resumo
O texto trata do universo crítico da peça Incêndios de Wadji Mouawad. Procura caracterizar as ações da personagem central, Nawal, como ponto de partida (e de chegada) da narrativa. Pontua os mecanismos de escrita e memória como disparadores do pensamento e da trama entre os elementos da peça. Nesse sentido, se atém à compreensão conceitual da noção de tempo, procurando localizar suas dimensões no drama. Encontra em Sófocles proximidade filosófica e instrumental com os elementos utilizados na construção das cenas. Por isso, paraleliza Incêndios com a obra clássica Filoctetes. A partir daí, sinaliza movimentos de criação das temáticas que se sobressaem e se relacionam nas abordagens dos enredos, apesar da distância temporal entre ambas. Procura ainda, lançar a temática da crítica social, apresentada pelo autor, para além do núcleo estético e cenográfico, expandindo essa análise para questões que envolvem problemas sócio demográficos contemporâneos. Por fim, tematiza a expressão infâncias do presente relacionando-a a noção de Infância Sem Fim (CORAZZA, 2000), problematizando o chamado dispositivo de infantilidade. Utiliza a compreensão conceitual de tal dispositivo para efetuar considerações sobre dois momentos da infância que se apresentam na peça. No primeiro momento, trata da origem do sentimento da personagem Nawal e, no segundo momento, trata da expiação desse mesmo sentimento, efetuando, assim, a condição trágica por excelência.
\end{abstract}

Palavras-chave: Infância; Tempo; Condição trágica

\section{Scenes from an endless childhood: the tragic feeling in incêndios}

\begin{abstract}
The present paper discusses the critical universe of the theatre play Incêndios, by Wadji Mouawad, taking the actions of the main character, Nawal, as both the starting point and the point of arrival of the narrative. It punctuates the writing and memory mechanisms as triggers for thought and plot among the elements of the play. In this regard, it attains to a conceptual comprehension of the notion of time, seeking out its dimensions in the course of the drama. It encounters in Sophocles' Filoctetes a philosophical and instrumental proximity. For this reason, Incêndios and the classical work are parallel. It also raises critic social themes over and above the aesthetic and scenographic core, expanding the analysis to questions that involve contemporaneous socio-demographic problems. Finally, it thematizes notions of childhood through problematizing the "childishness" trope most clearly displayed in the work Endless Childhood (CORAZZA, 2000). It uses a conceptual
\end{abstract}

\footnotetext{
${ }^{1}$ E-mail: sandracorazza@terra.com.br

2 E-mail: deniznicolay@yahoo.com.br
} 
analysis of this device to make considerations about two moments of childhood that are presented in the play. In a first moment, it discusses the origins of Nawal's feelings and, in a second, the atonement of she performs in resolution of these feelings, in a quintessential evocation of the tragic condition.

Key-words: Childhood; Time; Tragic Condition

\section{Escenas y tiempos de una infancia sin fin: el sentimiento trágico en Incendios}

\section{Resumen}

El texto se refiere al universo crítico de Incendios de Wadji Mouawad. Busca caracterizar las acciones del personaje central, Nawal, como punto de partida (y de llegada) de la narrativa. Puntúa los mecanismos de escritura y de memoria como disparadores de pensamiento y representación gráfica de los elementos de la pieza. En este sentido, se apega a la comprensión conceptual del concepto de tiempo, tratando de localizar sus dimensiones en el drama. Encuentra en Sófocles proximidad filosófica e instrumental con los elementos utilizados en la construcción de las escenas. Por lo tanto, en paralelo con Incendios está la obra clásica Filoctetes. A partir de ahí, se señala la creación temática de los movimientos que se interponen y se relacionan en los enfoques de las tramas, a pesar de la distancia temporal entre ellos. Asimismo, se pretende poner en marcha el tema de la crítica social, presentada por el autor, más allá del núcleo estético y escenográfico, ampliando este análisis a cuestiones relacionadas con problemas socio-demográficos contemporáneos. Por último, estudia la expresión "infancias del presente" relacionándola con la noción de Infancia sin Fin (CORAZZA, 2000), discutiendo el llamado dispositivo de infantilismo. Se utiliza de la comprensión conceptual de tal dispositivo para hacer un examen de las consideraciones sobre la infancia que se presentan en la obra. En un primer momento, se trata del origen del sentimiento del personaje Nawal y en un segundo momento es la expiación de ese mismo sentimiento, efectuándose así la condición trágica por excelencia.

Palabras clave: Infancia; Tiempo; Condición trágica 
Este texto apresenta uma sequência de observações (e relações), do ponto de vista da encenação trágica, sobre a peça Incêndios (MOUAWAD, 2013). Dessa forma, procura localizar fragmentos de instante, de memória que possam ilustrar o caráter da personagem central: Nawal. Parte da percepção do tempo e da distância dos sentimentos e, por isso, busca nas antigas tragédias gregas noções constitutivas na composição das cenas. Assim, esse texto se aproxima de Sófocles, mas, ao mesmo tempo, mantém a devida distância. Ele se aproxima ainda da noção de Infância Sem Fim (CORAZZA, 2000), uma vez que considera pertinente (e atual) a crítica do dispositivo de infantilidade. Desse modo, manifesta apreço pelas infâncias do presente, pela reflexão crítica que se sobrepõe ao discurso fatalista de nosso tempo.

\section{As areias do tempo}

A peça Incêndios de Wajdi Mouawad (2013) é extremamente prolífica em efeitos de sentido, dramas pessoais, jogos de cenas, narrativas cruzadas. Trata-se de procurar numa terra muito distante, do outro lado do oceano, fragmentos de vida para recompor o quebra-cabeça da vida presente. Por isso, o tempo se intercala, entretempo, ele tem um início na peça (a leitura do testamento de Nawal), mas não tem um fim previsível, mesmo que as personagens executem os passos do referido testamento e desvendem os segredos de Nawal. Existe um continuum residual (composto de imagens, detalhes, cidades) que permanece na memória dos espectadores. A narrativa nunca termina porque está presa no liame vital das personagens. Tal liame é como se fosse uma teia que se tece e retece à procura da fibra comum: a grande mãe ou o grande pai. Entretanto, não há uma origem de tudo, porque ela ultrapassa os tempos e os lugares. $\mathrm{O}$ drama pessoal e familiar de Nawal supera os limites do individual para universalizar-se na arte trágica. Assim como a trama das antigas tragédias gregas, sobretudo de matriz sofocleana, Wajdi Mouawad parte dos interstícios da alma humana para fazer rolar 
as águas de seu ananke 3 inevitável. Na maldição dos labdácidas, isto é, da linhagem de Édipo, por exemplo, as personagens são livres para escolher seu caminho; porém, cada escolha tem uma consequência e segue um curso incontornável até que o circulo se feche e cumpra integralmente a fala do oráculo (Édipo Rei, Édipo em Colono) (SÓFOCLES, 2006). Ou seja, a criação do mundo exterior, da convivência social e das relações, depende de uma projeção do mundo interior. Essa era a forma que as encenações trágicas, na Grécia antiga, encontravam para cativar virtudes nos seus expectadores. Entre amores e ódios, as personagens vagam pelo tablado da cena para encontrarem-se umas nas outras. É como um exercício de interdependência, no sentido que ninguém vive só, e que as ações transformadoras dependem do esforço coletivo. Dessa forma, a peça Incêndios provoca reflexão sobre valores humanitários, do que realmente importa no cotidiano das pessoas e, acima tudo, provoca o sentido da humanidade em nós.

Mas a reconstrução do passado, do passado de Nawal, só é possível por meio da grafia ou da escrita pessoal da personagem. Ou seja, a escrita testamentária é a escrita final da personagem; no entanto, ela sugere o início da história com a entrega dos envelopes aos irmãos gêmeos que, com cuidado, tem atitudes absolutamente diferentes. Por um lado, a filha Jeanne, estudante de matemática, fica apreensiva e curiosa sobre o conteúdo dos envelopes; por outro, seu irmão, Simon, boxeador amador, demonstra desinteresse pela escrita de tais envelopes. Mas é a insistência de Jeanne que levará ambos ao encontro da verdade, silenciada durante anos na memória de Nawal. Escrita e memória exercem aqui um papel edificante, pois é quando as vozes se calam na profusão do tempo é que uma palavra, um nome tem o poder de libertar os signos do passado. Cada linha, cada detalhe de composição, cada gesto de imagem carrega figurações de realidades, vividas e experienciadas por quem já abandou o tempo físico. Porém, só se pode reconstruir uma trajetória individual a partir desses pequenos vestígios. Se Nawal deixa cartas, uma espécie de mapa e horas e horas de gravações vazias,

\footnotetext{
${ }^{3}$ Na mitologia grega, era uma deusa da inevitabilidade, mãe das moiras e personificação do destino, necessidade inalterável e fato. Disponível em: <https://pt.wikipedia.org/wiki/Ananque> Acesso em: 20/06/2016.
} 
ela também procede como uma mente engenhosa. Na matemática, a teoria dos grafos estuda, entre outros conteúdos, as relações dos objetos em determinado conjunto $^{4}$ (não é aleatório que uma das personagens, Jeanne, se interesse por conjecturas matemáticas como também, por vezes, se expresse por meio delas), ou seja, existem pontos, arestas, quadraturas, linhas, todo um jogo matemático a serviço do tempo e das cenas. Em Incêndios predomina o número quatro, como um quadrado interligado por duas faces, uma aparente outra oculta, uma dentro, outra fora, uma aberta, outra fechada. A intensidade e o cruzamento entre as linhas de expressão de cada cena, ou de cada Incêndio, desconstroem noções fixas de tempo e lugar. E, como a obra é parte de uma tetralogia maior, tal forma de organização proporciona a ligação necessária com o palco da encenação, lugar onde a peça encontra sua conexão. Claro, a construção é fruto da singularidade do autor, mas também de uma personagem que, mesmo morta, conduz a trama. Nawal é como uma Moira que tece o fio da vida, seguindo os conselhos da avó Nazira: "Aprende a ler, a escrever, a contar, a falar: aprende a pensar. Nawal. Aprende" (MOUAWAD, 2013, p. 49). É essa escrita que significa a possibilidade de recriar passagens esquecidas, alimentando o drama psicológico das personagens.

Assim, torna-se coerente afirmar que em Incêndios, as infâncias do presente carregam as marcas de khrónos (mas não partilham dele), enfurecidas pelas mazelas da linhagem familiar. E, como o velho Titã que devora seus filhos, um por um, logo após o nascimento, também essa infância da obra, negada no brio da existência, há de se constituir como força de resistência aos efeitos devastadores do tempo. Por isso, as infâncias do presente partilham do tempo kairós, o antípoda de cronos. Kairós significa o instante singular e, portanto, não representa um tempo absoluto, contínuo ou linear, mas o momento apropriado em que a ação acontece. É de natureza qualitativa em detrimento ao aspecto quantitativo do velho ceifeiro de cabelos brancos ${ }^{5}$. Ele não reflete o passado, nem pressente o futuro, mas compõe um momento para toda vida. Quando Nawal, 'Incêndios da infância', recorda o

\footnotetext{
${ }^{4}$ Conferir Mariani (s.n.t). Disponível em: < http://www.inf.ufsc.br/grafos/livro.html> Acesso em 18/06/2016.

${ }^{5}$ Disponível em: <https://www.significadosbr.com.br/kairos> Acesso em 19/06/2016.
} 
ônibus queimado: "Não existe mais tempo, Sawda. Não existe mais tempo" (MOUAWAD, 2013, p. 77), ela revive os horrores da guerra por meio de imagens estarrecedoras, recorda os sons e os apelos dos refugiados. São mais de cinquenta anos de história que vão e vêm, personagens (vivos e mortos) que intercalam diálogos, culturas que se entrecruzam, compondo uma cosmologia cenográfica que, a cada recorte de tempo, instaura um quadro único. Ora, os antigos gregos acreditavam que kairós podia enfrentar cronos, uma vez que se apresentava mais jovem e ágil que seu oponente. Considerando que ele é esse tempo que amplia a percepção do presente, é provável que também tenha cristalizado fragmentos da guerra na mente da personagem central. Entretanto, ele não acumula memória, mas partilha da leveza e da rapidez. Com efeito, é Mnemosine (JULIEN, 2005) que liga o tempo à terra, fonte de perguntas e respostas sobre a origem de tudo, embora nem toda informação mereça registro. Ela seleciona e aplica o conhecimento de acordo com a sensibilidade do portador. É por isso que a personagem (Nawal), na peça, lembra-se de alguns eventos muito específicos, quase sempre relacionados à dor e ao sofrimento. Em algumas interpretações da mitologia grega Mnemosine aparece como irmã de cronos e kairós como filho de Zeus. Mas, para além das linhagens titânicas e olímpicas, importa referir que as infâncias do presente em Incêndios igualmente partilham essa tríade funcional cronos-Mnemosine-kairós, exatamente nessa ordem. O tempo, a memória e o instante extraordinário provocam efeitos de sentido, de compreensão da trama e, por isso, perpassam a lógica dos espaços vividos, desconstruindo a consciência identitária do ser infantil. Assim, não há uma infância singular, mas infâncias que se enovelam na miséria humana.

Aliás, a definição de infância da personagem que representa o primeiro amor de Nawal, Wahab, é curiosa e, ao mesmo tempo, profética: “Nawal, hoje à noite, a infância é uma faca que estão enfiando no meu pescoço" (MOUWAD, 2013, p. 45). Curiosa porque é comparada a uma faca, uma forma de assassinato, do pai que perece para o nascimento do filho. Wahab é forçado a sair de sua terra, do lugar de sua infância e, provavelmente, não verá seu filho nascer. Profética porque 
o nascimento dessa criança significará a desgraça de Nawal. O fruto do amor inocente, levado por Elhame para os lados do sul, será alimentado pelo desprezo e pelo ódio, tornando-se um cruel assassino. Depois do nascimento dos gêmeos (Incêndio de Sarwane), quando Simon lê a carta de Nawal, aparece a mesma definição: “A infância é uma faca enfiada no pescoço" (MOUWAD, 2013, p. 130). Ou seja, o tempo só prolongou o sofrimento, mas Nawal precisa que os filhos descubram o segredo incestuoso para alcançar a redenção. É preciso reconstruir a história e quebrar o ciclo de desgraças familiares. É preciso que o amor vença o ódio, eis a grande mensagem da peça. A obra é uma tragédia pós-moderna e as infâncias do presente estão por todos os lados. Elas estão no campo de refugiados em Calais, no noroeste da França; em Dadaab, no Quênia; em Kawergosk, no Iraque; em Atmeh, na Síria; em Kigoma, no noroeste da Tanzânia. Elas nascem e vivem em zonas de guerra no Oriente Médio. Elas foram vítimas do massacre de Realengo, da chacina de Candelária. Elas trabalham nas minas de carvão do norte e nordeste do Brasil. Portanto, a peça expõe um problema de significação social, presenciado em nosso tempo pelas guerras e pela exploração financeira do grande capital.

\section{O sentimento trágico em Incêndios}

É coerente afirmar que Wajdi Mouawad organiza a produção textual de Incêndios inspirando-se nas antigas tragédias gregas (séculos VI e V a.C.). Já referimos sua proximidade com Sófocles. Mas porque Sófocles e não Ésquilo ou Eurípedes? Porque os elementos esquilianos são demasiados primordiais, titânicos ou teofânicos. Eurípedes representa a fase final da tragédia grega, substituiu a antiga Moira pelo Eros civilizacional, ou seja, por ser o mais jovem dos três grandes poetas trágicos, ele populariza mecanismos de persuasão e montagem, a fim de desmistificar os efeitos trágicos da cena, descaracterizando o vínculo original da tragédia com o universo místico religioso do povo grego (BRANDÃO, 1985). Mas isso também por obra dos efeitos da sofística e do ambiente democrático da Pólis. Já em Sófocles, assistimos ao exercício da construção de dramas antropomórficos, materializando o amor e o ódio genealógico. A semelhança de Incêndios com Édipo- 
Rei (SÓFOCLES, 2006) é imediata, Jocasta revive Nawal, mas não há Édipo encarnado na peça de Mouawad, tampouco a verdade é revelada no início como no clássico de Sófocles. Esteticamente as obras se aproximam, talvez porque sustentem a seguinte máxima do drama trágico: “A arte do grande poeta consiste em revelar-nos seus pensamentos sem fugir à textura da obra de arte" (LESKY, 2003, p. 148). Isso significa que Mouawad precisa pensar na composição do caráter de cada personagem, não apenas pela necessidade de representação visual da peça, mas porque cada personagem é um encaixe do quebra-cabeça, como um mosaico turco cujos ladrilhos minúsculos estampam a tonalidade predominante da obra. As falas das personagens mais velhas transcendem o espaço comum dos signos vulgares, servem como metáforas do segredo terrível. O mecanismo trágico se afirma numa dupla causalidade, como se fossem as faces de uma moeda: a face do destino e a face do homem. Ou seja, por meio desse mecanismo, sabemos que a trama tem um destino inevitável, estarrecedor; entretanto, isso não elimina a responsabilidade individual de cada personagem. É como se essas duas faces coexistissem, emitissem signos, uma à outra, afim de que, em algum momento, o círculo se quebre. É nesse sentido que aparece a afirmação de Nawal no desfecho da peça: "As mulheres de nossa família estão todas presas numa teia de raiva“[...]É preciso quebrar esse fio [...]" (MOUAWAD, 2013, p. 131). O apelo da personagem é pelo rompimento de uma sina, a sina da dor, pois somente dessa forma aquela que está morta poderá tornar os vivos melhores. Isso caracteriza o estilo clássico da peça, a engenhosidade que provoca o sensível. Os pensamentos que questionam valores e, sobretudo, os princípios que afirmam os pilares da civilização. Logo, distinguindo razão e desrazão, pequenez e grandeza, afirmação e negação.

Tais considerações transcendem o palco real da encenação. O palco é o mundo e a narrativa dramática, sua origem em terras distantes, compreende a passagem da ignorância ao conhecimento. É muito claro o cunho social e transformador da peça, assim como seu distanciamento do romantismo, do idealismo ou de qualquer matriz de acepção burguesa. Existe uma concretude encarnada na representação. Tudo é tão real a julgar pela compreensão do leitor e, 
quiçá, do espectador. Theatrum mundi da vida cotidiana, cuja função dos seres humanos é servir de fantoche ao egoísmo e à hipocrisia, semelhante ao Mito da Caverna de Platão (2008). O palco da encenação torna-se um jogo de xadrez onde nós somos as peças. A sequência dos dias e das noites (inevitável cronos) são os quadrados brancos e negros por onde nos movemos. No percurso até o outro lado do tabuleiro, acreditamos que alguns possuem mais poder e influência que outros, mas todos acabam rumando para dentro da mesma caixa. Mas quem é o jogador que nos move? Há de se concordar com a afirmação de Romilly (1998, p. 22): "Cada tragédia significava presença, e uma presença aterradora". Embora ela se refira às antigas tragédias gregas, em Incêndios essa presença perpassa as cenas. É o fantasma do outro desconhecido, o silêncio de Nawal, o pecado e o medo, o desterro dos filhos e o abandono do pai, mas, acima de tudo, é o arrependimento da personagem central. No tribunal dos homens, Nihad é condenado, vítima e algoz e, assim como Édipo, fura seus próprios olhos, ele deverá ter coragem para esvaziar-se da vida; porém, a trama encerra-se antes deste ato. Ora, estamos diante de um teatro social engajado, de uma problemática contemporânea que assola todos os povos. Talvez haja certa proximidade com Brecht (1898-1956), na utilização de técnicas e dispositivos a fim de provocar a análise crítica do leitor (ou do espectador). Tal análise, portanto, não tem outra razão que não seja o despertar da consciência política e democrática das nações.

\section{Filoctetes e Nawal}

À primeira vista uma personagem não tem nada a ver com a outra. São distantes em todos os sentidos. Então, qual a relação possível? Já tratamos de alguns elementos edipianos em Incêndios (mesmo sem o Édipo revelado). No entanto, a utilização de um esquema trágico institucional extremamente simples, como o que é utilizado por Sófocles no Filoctetes (a penúltima das sete tragédias conservadas e encenada em 409 a.C.) pode nos trazer detalhes comparativos, literários e estruturais com Incêndios. A lenda é conhecida no universo homérico, porém, menos importante quando comparada aos grandes heróis da Grécia. O guerreiro Filoctetes, portador do arco de Hércules, é abandonado na ilha de 
Lemnos por seus compatriotas, após ser picado por uma serpente. A ferida nunca cicatriza e por dez anos vive isolado na ilha. Mas, após inúmeras batalhas, os heróis da Grécia são avisados por um oráculo que só conseguiram tomar Tróia se contar com a presença de Filoctetes e seu arco. Odisseu convence o jovem Néoptólemo, filho de Aquiles, a enganar Filoctetes e trazê-lo novamente ao front de batalha. De pária a herói, eis a breve sina do miserável personagem. Mas são os elementos utilizados por Sófocles que nos permitem traçar paralelos com Nawal. Uma ferida que nunca cicatriza, o abandono, o silêncio, o retorno ao passado como condição de compreensão do presente, a redenção na imagem do menino. Essas são ações que poderiam ser aplicadas tanto numa tragédia quanto na outra. Embora Filoctetes não comporte nenhum papel feminino, talvez pelo respaldo institucional e jurídico da Pólis grega da época, existe um universo sensível que brota de cada verso. Em Incêndios, ao contrário, a potência afirmativa feminina é definitiva para a mudança de caráter das personagens. Os irmãos gêmeos, por exemplo, sofrem uma espécie de mutação durante a peça. Eles vão sendo melhorados, melhorando-se ao descobrir os segredos de Nawal. No Filoctetes também, pois o jovem Neoptólemo inicialmente aceita o plano ardiloso de Ulisses para roubar o arco do herói; no entanto, após conversar com este, o jovem muda radicalmente seus planos. Outra relação próxima é a interdependência tempolugar. Além do que assinalamos anteriormente, importa saber que o lugar da ação manifesta a compreensão geográfica da condição social da personagem. O homem é húmus, é terra, é barro, é argila do continente onde nasceu, por isso é simbólico o pedido de Nawal durante a leitura do testamento: "Me coloquem no fundo de um buraco, com a cara contra o mundo" (MOUAWAD, 2013, p. 25). Numa atitude de humildade e desprezo, a personagem assume o peso da condição humana, afirma a sua absoluta imperfeição. Ainda nessa linha, estendendo-a para o Filoctetes, cujo isolamento na ilha de Lemnos provoca-lhe a extração dos mais profundos instintos de sobrevivência (próximos do mundo animal), há de se aproximar da barbárie de Incêndios, da selvageria que cruza naturalmente o mundo civilizado. Porém, não são mundos muito distantes se considerarmos a construção cultural da vida em 
sociedade. Um fio tênue separa civilização e barbárie. Assim, a peça mostra que não existe tempo definido, nem evolução dos sentimentos, mas uma sequência de erros e acertos à mercê das forças da natureza. Filoctetes é o eu masculino de Nawal, ainda que Nawal não seja o eu feminino de Filoctetes, ela se mantém como uma verdadeira heroína de resistência ao mundo bestializado.

\section{Infâncias do presente e Infância Sem Fim}

Se há uma infância em Incêndios, ela não personifica nenhum personagem. Com efeito, não há ator na peça que represente uma criança. Das idades da vida, a infância está fora. A infância de Nawal, por exemplo, acontece em meio à pobreza, a guerra e a miséria. Próximo ao caos e ao extermínio, não há espaço para a manifestação do sentimento moderno de apreço pelas crianças. Mesmo que esse sentimento seja fruto do drama burguês, como assinala a história das mentalidades de Philippe Ariès (1981) é possível afirmar que, nos campos de refugiados, não chegam presentes de natal. "A infância é uma faca enfiada no pescoço", eis a máxima que predomina no texto. Na estrutura da peça, ela simboliza o início e o fim, uma espécie de morto social que carrega a esperança nos ombros. Ao transpor tal problemática para o contexto das discussões políticas, econômicas e culturais contemporâneas, Mouawad pretende abrir os olhos do mundo, denunciar que não há futuro para as crianças se não tratarmos as feridas do presente. É cronos que devora seus filhos, pacientemente, sem nenhuma possibilidade de libertação. No entanto, o tempo ideal desse ser infantil é o tempo Aion porque partilha do presente transformador. Tempo de intensidades, de brincar com os números e com as pedras ao modo heraclitiano. Nele, o poder criador e imagético se manifesta como um momento à parte do tempo cronos (KOHAN, 2004). Por isso, há a necessidade de se reinventar a experiência, distante da maldade e do ódio, para que, assim, crianças não empunhem fuzis, meninas não sejam violentadas, mães e pais não chorem a morte de seus descendentes.

Nesse sentido, aproximamos a temática das infâncias do presente com a expressão "infância sem fim" (CORAZZA, 2000), uma vez que colocamos em evidência questionamentos que circundam a passagem entre a infância moderna 
para, talvez, a infância contemporânea. Mas porque referimos esse "talvez"? Porque não há nenhuma clareza absoluta quanto aos movimentos transculturais, de messianismo religioso, de intolerância entre povos de uma mesma nação, ou seja, do que realmente irá acontecer daqui há uma ou duas décadas nos campos de refugiados, por exemplo. Não sabemos se ocorreu uma passagem na história ou se ela nunca existiu. Tal afirmação é mais coerente e cuidadosa hoje depois da verificação de vários eventos de natureza econômica ocorridos após os anos noventa. Falávamos no "fim da história" (FUKUYAMA, 1992) e, por consequência, no fim da infância (POSTMAN, 1999). A presença do novo milênio que se anunciava trazia consigo o debate de muitos problemas, sobre a organização da vida e do mundo. É evidente que as diretrizes pós-modernas em relação aos efeitos culturais são mais antigas, mas só se vislumbraram com intensidade nos anos setenta, oitenta e noventa. É nessa linha, também, que operamos com o que denominamos "dispositivo de infantilidade" na intenção de erigir análise crítica sobre o suposto "fim da infância". Daí uma de nossas problemáticas essenciais: “Em outras palavras: existiria uma ruptura histórica entre a 'Idade da Infância', a análise crítica do 'Fim da Infância' e os anseios e práticas culturais em prol de uma 'Infância Sem Fim'” (CORAZZA, 2000, p. 29)? Com efeito, só sabemos de uma concepção quanto da outra por artifícios do aparato simbólico da linguagem. São os mecanismos tecnopolíticos de produção de sentido que operam a tríade podersaber-verdade. Eles fazem essa tríade funcionar como uma máquina de atualização e reatualização de dados estatísticos, mormente apregoadas pelas mídias de comunicação e pelo gerenciamento econômico das grandes potências. Ora, certamente quem escreve a história e quem manipula o dispositivo de infantilidade não são os habitantes dos campos de refugiados. A infância é tão vítima quanto o que se fez dela por meio desse dispositivo. Ela é um excedente da história e da produção desordenada e, por isso, está à margem do tempo e das sociedades civilizadas. Ainda é muito atual o apelo do autor do Desaparecimento da Infância: “Não é concebível que nossa cultura esqueça que precisa de crianças. Mas está a caminho de esquecer que as crianças precisam de infância" (POSTMAN, 1999, p. 
167). Seu repúdio serve perfeitamente no contexto de Incêndios, mais pelo núcleo da crítica social levantada do que pela estética cenográfica. Portanto, "infâncias do presente" e "Infância Sem Fim" estendem linhas sintomáticas de proposição e juízo. Não é possível compreender as matérias do presente sem recuarmos na história e analisarmos os avanços (e retrocessos) do grande capital. Trata-se de um estudo geopolítico, observando o desenvolvimento dos dispositivos institucionais de uma nação ou país, aliado de ferramenta crítica genealógica que avalie as dimensões (e intensidades) do jogo de forças presentes na política e no controle econômico. Mas, assim como Incêndios já queimou os quadrados das cenas, um estudo estrutural nessa direção implicaria extrapolar os limites do presente texto e, por consequência, também queimaria seu fundamento e intenção.

Importa saber que a noção de "dispositivo de infantilidade" é tributária da esteira foucaultiana. A infância, como as demais composições da subjetividade contemporânea, foi objeto de estudo e análise do filósofo. Talvez menos a condição etária da criança, mas, de um modo geral, o sujeito como instância nuclear da modernidade. Desse modo, associamos o termo dispositivo à infância para tratar dos modos de subjetivação e produção do ser infantil. Ora, se a compreensão foucaultiana acerca do termo "dispositivo" parte da análise das sociedades disciplinares dos séculos XVIII e XIX, sobretudo pela percepção da mutação sofrida pelo mecanismo conhecido como "Panoptismo", torna-se coerente aproximar este termo das praticas culturais de nosso tempo e, sobretudo, das ponderações que assinalamos na obra História da infância sem fim (CORAZZA, 2000). Ainda sobre tal mecanismo, é esclarecedora a definição dada por Deleuze (1988, p. 43): “A fórmula abstrata do Panoptismo não é mais, então, 'ver sem ser visto', mas impor uma conduta qualquer a uma multiplicidade humana qualquer"6. Ou seja, trata-se de elucidar formas de agenciamento e controle, inseridas no próprio espaço de convivência social, cujo motor propulsor é uma engrenagem informe, imperceptível, mas que exerce atividade direta na vida das pessoas. É uma pragmática de governo mais diluída, mais sensível que os modelos repressores da Idade Média, porém com

\footnotetext{
${ }^{6}$ Grifo do autor.
} 
mais potência e capilaridade quando se trata da produção discursiva e dos efeitos de sentido. Essa máquina complexa (e produtiva) receberá de Deleuze (1988, p. 44) o nome de "diagrama". Com efeito, a noção de diagrama se aproxima da noção de dispositivo e não seria absurdo equalizar procedimentos e metodologias de pesquisa nessa direção. Isso faz com que pudéssemos afirmar, a partir dessa perspectiva que: "[...] o dispositivo forma um conjunto multilinear, composto por linhas de diferentes naturezas que não abarcam sistemas, onde cada um é homogêneo por sua conta, tal como o sistema do sujeito, do objeto e da linguagem" (CORAZZA, 2000, p. 46). É claro que tivemos o cuidado de observar, nessa afirmação, as três grandes instâncias analisadas por Foucault, ou seja, as instâncias do saber, poder e da subjetividade. Ao mesmo tempo, tratando-se do dispositivo de infantilidade e de sua constituição diagramática é oportuno que manifestássemos intenção de mapear o terreno por onde essas linhas discursivas pretendiam trilhar significados acerca da história da infância. Não apenas da história, compreendida como ciência que estuda o passado da humanidade, seu processo de evolução (linear, temporal), mas uma espécie de história do presente que põe em evidência a genealogia das relações de força entre o regime de enunciados. Dessa forma, a própria história é duplicada de maneira coextensiva a todo campo social. Ela nunca é definitiva, mas parte de pontos de emergência (e proveniência) que se entrecruzam em continuuns temporais. Portanto, tratar de infâncias do presente é conjuntamente considerar tais aspectos teóricos metodológicos sobre uma analítica dos modos de subjetivação contemporâneos, quer seja na realidade das grandes cidades, quer seja no contexto da peça Incêndios.

Aliás, a partir desses apontamentos, considerando o dispositivo de infantilidade, podemos tentar compreender parte da trama que envolve a personagem Nihad. Ele foi abandonado quando nasceu por Nawal, persuadida por sua mãe Jihane. As razões desse ato não são muito claras na peça, presumimos que em decorrência da miséria familiar e da pouca idade de Nawal, que contava quinze anos quando do nascimento da criança (era um menino, Nihad). Ele foi levado por Elhame após o nascimento, mas Nawal promete: “Aconteça o que acontecer, te 
amarei para sempre! Aconteça o que acontecer, te amarei para sempre!" (MOUAWAD, 2013, p. 47). E, num último gesto de despedida, Nawal coloca um nariz de palhaço nas fraldas da criança. De alguma forma, esse gesto marca o início dos percalços pelos quais passou a personagem central. A referência ao nariz de palhaço aparece mais uma vez, ao final, quando Nihad está sendo julgado por seus crimes, inclusive pela tortura da própria mãe. Ele refere: "Minha dignidade é uma careta deixada por aquela que me deu a vida. Essa careta nunca me deixou" (MOUAWAD, 2013, p. 125). Então, ele coloca o nariz e canta uma canção, não da mulher que canta, mas do seu próprio repertório. Ou seja, parte do enredo se fecha, simbolicamente, com o nariz de palhaço. Mas como atravessarmos o dispositivo de infantilidade nessa direção? A partir do que assinalamos no texto, Nihad foi tão vítima dos mecanismos de produção de subjetividade quanto culpado de seus crimes. Ele era uma peça da engrenagem da máquina social abstrata, uma espécie de fantoche guiado por outros interesses. E, se ele tivesse nascido (e criado) fora do campo social onde viveu e cresceu, qual seria o desfecho da história? É disso que se trata. Ora, Nihad costumava fotografar suas vítimas como um palhaço cruel da sociedade do espetáculo, colecionador de imagens vazias. Claro que essa não era a intenção de Nawal, o nariz deveria significar inocência e alegria; porém, convertese em rancor e desprezo. Mesmo assim, há que se admirar o brio da personagem central, aquela que conta histórias dentro da história.

\section{Verdade, narrativa e expiação}

Também é por meio de sua boca que ouvimos, ao final da peça, na leitura do envelope, a seguinte afirmação: "Há verdades que só podem ser reveladas se forem descobertas." (MOUAWAD, 2013, p.132). Essa concepção de verdade, manifestada pela personagem central, merece atenção na medida em que implica a compreensão da essência narrativa do drama. É como se tal personagem exercesse a função de oráculo que decodifica o presente e o passado. A escrita do envelope que, de alguma forma, personifica a fala de Nawal, traz até a cena um quadro de acontecimentos capazes de recriar a história de vida de cada indivíduo envolvido na trama. Ela abre a possibilidade de se reescrever, a partir daquele instante, da 
leitura da carta, uma gama de experiências produtivas, porque seus atores já sabem de onde vieram, mas, obviamente, não sabem para onde vão. Essa forma de presentificação do tempo é própria dos efeitos da ação narrativa desenvolvidos pelo autor da peça, porém partilhada pela personagem que narra o evento. Ou seja, isso faz com que se possa diminuir a distância entre os elementos do enredo e a sequência dos acontecimentos que dão continuidade aos atos de fala. Dessa forma, entendemos que o conjunto trágico evidenciado por Incendios se prende num jogo complexo de sentidos e representações imagéticas que põem em movimento episódios construídos, acima de tudo, para o campo do tablado cenográfico. Já na Poética, encontramos a definição de quatro tipos de tragédias: a complexa, a patética, a de caráter, as de monstros (Cf. ARISTÓTELES, 2005, p.39). Ora, pela engenhosidade ficcional da peça, pelas idas e vindas do discurso narrativo, diríamos que a obra de Mouawad se enquadra na primeira definição aristotélica. Ainda que tal afirmação possa parecer precipitada, uma vez que a preocupação do velho estagirita está muito mais na distinção entre tragédia e epopeia e na descrição da linguagem poética do que em classificar a constituição complexa da tragédia; ainda assim, pela riqueza de elementos nessa direção (que fazem parte da peça) é justo sinalizarmos tal atributo. Mas as aproximações param por aí, pois ocorre o risco de transformarmos a estética do drama cênico numa série normativa de gestos e falas, além de moralizar o discurso das personagens. Com efeito, quanto menos cristianizarmos a obra, quanto menos utilizarmos categorias de juízo e redenção, tanto mais será possível decifrar (e apreciar) as passagens do jogo dramático. Inclusive, o efeito catártico não segue a regra definida pela Poética, qual seja, a regra de inspirar "pena e temor" no espectador a fim de que este "opere a catarse própria dessas emoções" (ARISTÓTELES, 2005, p.24). Claro, não temos como apreciar o sentimento e as emoções desses espectadores, uma vez que se trata da representação de uma ação (mimeses), do instante específico em que ela ocorre. Além do mais, o conceito de catarse não tem uma tradução precisa a partir da Poética. No drama moderno, por exemplo, tal conceito se aproxima das ideias de 'purificação', 'compensação', ou seja, de uma descrição moralizada acerca da 
tragédia antiga. No entanto, sabemos por meio do livro VII da Política de Aristóteles (2010) que, ao tratar dos efeitos catárticos da música, ele sinaliza para o caráter terapêutico de tal conceito. Identifica este como uma espécie de 'descarga de emoções' capaz de melhorar os sintomas vitais, mas apenas no momento em que ocorre a ação. Acontece que Nawal foge à regra, já que está morta na ocasião da leitura das cartas e, portanto, o efeito catártico não se aplica a presença da personagem. Ela não é melhorada pelo evento. No entanto, na memória de seus filhos, ela assume atributos (ou caracteres) que vão personificando uma imagem positiva da mesma. Por meio dessa imagem, o autor se utiliza como guia da narrativa, sem a qual as personagens não chegariam ao conflito pulsional da obra. Ou melhor, não chegariam a 'desvelar a verdade' que já estava presumida de antemão, porém foi sendo construída por cada um dos filhos. Em razão disso, devemos aproximar Incêndios da antiga forma da tragédia grega de interpretar o evento (ou o acontecimento), chamada por Nietzsche (2006) de 'Ereignis'. Nesse ponto, não devemos entrar no mérito da compreensão heidegerriana da expressão, mas na ênfase destacada pelo filósofo de Sils Maria, já que tal linha de interpretação (a de Heidegger) foge do contexto de nossa abordagem. É na Introdução à tragédia de Sófocles (2006) que Nietzsche diferencia a tragédia grega da tragédia moderna, utilizando esse termo (Ereignis) para referir-se ao instante trágico como uma experiência direta e imediata do publico presente. Era como se ocorresse uma espécie de exercício democrático baseado na aceitação dos diferentes (mulheres, escravos...). Nas suas palavras: “Reunião total do povo, que reencontrava seus representantes no coro (vox populi) e seu ideal nos heróis, que eram habituados a entender tudo politicamente como homens políticos por excelência." (NIETZSCHE, 2006, p.58, §3). Esse é um momento em que a tragédia grega, no ambiente da polis, não é deturpada pela atmosfera da corte como será posteriormente com Eurípedes. A mesma sina ocorre com a tragédia moderna, ela não é mais popular, mas apenas um artifício de distração das massas. Entendemos aonde Nietzsche quer chegar ao atribuir essa expressão (Ereignis) ao estado de presença do drama trágico. Significa o desencadeamento do 'inédito possível', cujo 
desfecho não é preconcebido de antemão, mas imprevisível e instantâneo. Não é aleatório que o filósofo irá atribuir importância maior à noção de pâthos que, necessariamente, a concepção aristotélica de ação na tragédia clássica. É o pâthos que aproxima os indivíduos e, ao mesmo tempo, os afasta do vitalismo estético grego. Espécie de mediador entre o sentimento trágico e a dimensão afetiva do conhecimento humano. Por isso, a noção de verdade na narrativa, sobretudo na fala de Nawal, vai nessa direção, ou seja, na direção de Ereignis. A verdade como acontecimento, que se desenrola conforme o grau de afecção investido por seus atores. Logo, não há verdade no sentido metafísico do termo, mas sinais que ocorrem diante de nossos olhos e que determinam a sequência dos fatos.

São esses sinais que auxiliam na construção do aparato discursivo responsável pelas mudanças entre as personagens. Jeanne, por exemplo, que media os problemas do cotidiano semelhante à resolução de conjecturas matemáticas, de maneira lógica racional, acaba desabafando: “Hoje, aprendi que é possível que do ponto de vista que ocupo, eu possa ver também meu pai; aprendi também que existe um outro membro desse polígono, um outro irmão." (MOUAWAD, 2013, p.38). Isto quer dizer que a quadratura da história de vida da personagem não está completa, falta um ângulo, uma linha desconhecida e invisível. É quando o olhar se detém na possibilidade de traçar outros planos e avista algo na periferia da retina, mas não identifica a natureza do objeto. Por isso, se abre para o desconhecido, para o lado oposto do polígono que jamais aparece porque está encoberto pela lembrança do sofrimento. Esse impulso à procura da verdade, por parte de Jeanne, independe da ordem lógica dos fatos. A probabilidade de que o pai, e o irmão perdido, estejam vivos é muito pequena. Tampouco a sentença especular de que ambos são a mesma pessoa, já que essa é uma hipótese mais distante ainda da visibilidade concreta do polígono. No entanto, Jeanne desconfia do que é dito, do cálculo exato, pois não acredita no que não vê (nunca viu o pai ou o irmão morto), nem naquilo que lhe contaram quando ainda era criança. Então, decide assumir a escrita de seu destino, procurando vestígios, pistas, signos sonoros capazes de recriar uma história, como a estória de um conto daqueles das mil e uma noites. 
Nesse caso, verdade e ficção estão muito próximas, não se sabe qual delas produz a outra, não há certeza nos enunciados escritos, nem nas vozes proferidas no discurso. As palavras podem enganar os ouvintes. A sentença de Nawal é clara: “[...] As palavras são horríveis. É preciso ficar lúcido. Enxergar. Fazer como os antigos: tentar ler presságios no voo dos pássaros. Adivinhar. " (MOUAWAD, 2013, p.80). Significa que toda verdade é apenas interpretação de interpretação. Cada palavra que vem a luz carrega o peso condicionante das estruturas da linguagem, das teias gramaticais. Elas (as palavras) são limitadas, uma vez que existem acontecimentos que elas mesmas dificilmente assimilarão. Tal perspectiva é partilhada por Nietzsche na obra Sobre verdade e mentira (2008). Em algumas traduções essa obra recebe um complemento no título: o termo extramoral, intitulando-se Sobre a verdade e a mentira no sentido extramoral. Talvez seja o período mais cético da produção do filósofo, período em que associa a verdade ao aniquilamento da espécie humana. Em contrapartida, inspirado na tragédia ática, ele vê a arte como a única alternativa para salvação do espírito. Agora, a verdade em oposição à mentira é uma criação da atividade gregária da civilização no seu longo processo de interiorização do homem. Por conseguinte, como uma espécie que precisa sobreviver e dominar a outra, o homem de rebanho atribui o nome de verdade a tudo aquilo que pode preservá-lo e, de mentira, o que pode destruí-lo ou descartá-lo; daí, as palavras serem usadas pelo seu grau de utilidade em determinada ocasião. Pode-se acompanhar Nietzsche quando questiona: "O que é, pois, a verdade? Um exército móvel de metáforas, metonímias, antropomorfisimos, numa palavra, uma soma de relações humanas que foram realçadas poéticas e retoricamente, transpostas e adornadas [...]" (NIETZSCHE, 2008, p.37, § 1). Aqui, o filósofo critica a superficialidade da linguagem que utilizamos, já que apenas reproduzimos sentenças canônicas balizadas por séculos de civilização. Reproduzimos modos de fala e de representação do pensamento, utilizamos conceitos chaves para definir um objeto, mas nunca investigamos a natureza das expressões socialmente aceitas, tampouco questionamos a validade dos nomes. É como se, ao nascer, o ser humano entrasse numa máquina de decodificação de 
signos cujos valores e sentidos fossem determinados de antemão. Com isso, Nietzsche, por meio da valorização do senso estético das artes, quer destacar a importância de determinadas virtudes, tais como o esquecimento e a intuição. A primeira porque significa uma forma de esvaziamento das pseudoverdades que marcam a existência e, a segunda, porque proporciona o raciocínio imediato sobre determinada ação, refutando, assim, os domínios da razão. Também Jeanne se vale dessas virtudes quando não aceita a comodidade dos fatos, deixa-se levar pelo relato improvável da carta póstuma. Ela compreende que a verdade é uma ficção, depende da potência e da sinergia do evento e, portanto, muitas páginas ainda estão para serem escritas.

Já falamos da possibilidade de realizar uma leitura descristianizada de Incêndios ou, quando muito, evitar o hábito de julgamento moral das cenas que compõem o enredo. Isso porque é muito fácil enquadrar as personagens num rol de caracteres estereotipados. Assim, encontramos o velho, a mocinha, a heroína, o bruto, a velha, até mesmo o vilão. Mas não se trata de elencar arquétipos cenográficos à peça de Mouawad, ela não ocorre nessas condições, nem é possível enquadrar as personagens num único tipo. Com efeito, a tipologia de Mouawad não se enquadra num esquema clássico de representação da vida cotidiana. Por vezes, a peça parece com a vida mesma, dado o peso realístico da trama. É o movimento das falas e o uso do tempo que deslocam as personagens do lugar comum da encenação dramática. Isso evita uma série categorizada de ideias prontas, rolls e clichês. Nawal, por exemplo, é representada em três ou quatro momentos da vida. Claro, todos são importantes e necessários ao conhecimento do drama. Mas é esse entrecruzamento de falas, tempos, regiões, idades que proporcionam a riqueza de detalhes, a produção do evento. Ainda em relação à Nawal, como a peça inicia com a morte da personagem é de praxe no drama trágico procurar o bode expiatório. Ou seja, aquele indivíduo que é responsabilizado pelos pecados da humanidade e, como tal, deve sofrer martírios até alcançar a redenção. Ora, sabemos que prolongar o sofrimento é uma especialidade da tragédia edipiana e, na religião, o próprio fundo trágico 
dionisíaco serviu de matriz para a morte de Cristo. Entretanto, não devemos conceber nem uma forma de expiação nem outra. Afinal, por quais falhas e erros Nawal foi condenada? Quem deve ser culpado pelos erros genealógicos que transcorrem na peça? Essa procura é infinita porque partilha do sentido trágico original, espécie de niilismo intrínseco a condição humana. Vamos encontrá-lo na sabedoria céptica do velho Sileno na obra O nascimento da tragédia de Nietzsche: “Estirpe miserável e efêmera, filhos do acaso e do tormento! Por que me obrigas a dizer-te o que seria para ti mais salutar não ouvir? O melhor de tudo é para ti inteiramente inatingível: não ter nascido, não ser, nada ser." (1992, p.36, §1). Tal passagem ilustra o pessimismo que brota da tragédia grega e, por isso, segundo Nietzsche, a revigoração do campo estético dionisíaco-apolínio. Significa, sobretudo, no âmbito de Incêndios, que não há um culpado individual pelas mazelas do destino. Nenhuma heroína como Nawal, por exemplo, deve sofrer as consequências por seus atos. O que existe é a transposição de um drama da própria humanidade, de maneira que os erros, as falhas são comuns a todos. Talhada pela imperfeição, a humanidade segue seu caminho acreditando nas metáforas que ela própria inventou. E, quem sabe, toda essa trajetória não seja apenas um conto ou uma canção de ninar.

Agora, se a infância é 'uma faca enfiada no pescoço' é porque o sofrimento se prolonga por décadas. É preciso retirar essa faca, fazê-la embainhar um cabedal de misérias e tormentos. Talvez a ação mais complexa seja exatamente o ato de retirar essa faca e refletir sobre o que fazer depois. Não é o passado que condena o erro, porém, as verdades que inventamos para justificar a frieza, a desfaçatez frente aos horrores do presente.

\section{Considerações finais}

Qualquer estudo que se faça sobre a peça de Wajdi Mouawad, Incêndios, acarreta a possibilidade de incorrermos no reducionismo de conteúdos e na pobreza de expressão. Trata-se de uma peça de teatro e é como tal que deve ser analisada, de modo que tudo que fizemos até aqui mereça a nomenclatura de estudo parcial sobre a temática social provocada pelo drama trágico da 
personagem. A riqueza dos detalhes, o movimento das cenas, a caracterização dos atores, a incorporação das falas e a habilidade de interpretação estão fora dessa análise. Da mesma forma, não se deve entender que partimos de uma simples resenha crítica sobre a peça, pois, deste modo, teríamos que assisti-la várias vezes para contrapor enredos. Tal procedimento poderia, ainda, criar uma espécie de psicologização do texto escrito. Se assim pareceu ao leitor, não foi essa a intenção. Apenas estendemos linhas possíveis, sem individualizar a análise. Num universo poético de muitas interpretações, esta é apenas uma delas.

\section{Referências}

ARISTÓTELES. A poética clássica/Aristóteles, Horácio, Longino. Tradução Jaime Bruna. São Paulo: Cultrix, 2005.

. A política. Tradução Nestor Silveira. São Paulo: Folha de São Paulo: 2010.

ARIÈS, Philippe. História social da criança e da família. Tradução Dora Flasksman. Rio de Janeiro: LTC, 1981.

BLACKBURN, Simon. A república de Platão: uma biografia. Tradução Roberto Franco Valente. Rio de Janeiro: Jorge Zahar, 2008.

BRANDÃO, Junito de Souza. Teatro grego: tragédia e comédia. Petrópolis, Vozes, 1985.

CORAZZA, Sandra Mara. História da infância sem fim. Ijuí: Ed. Unijuí, 2000.

DELEUZE, Gilles. Foucault. Tradução Claudia Sant'Anna. São Paulo: Brasiliense, 1988.

FUKUYAMA, Francis. O fim da história e o último homem. Tradução Aulydes Soares Rodrigues. Rio de Janeiro: Rocco, 1992.

JULIEN, Nadia. Tradução Denise Radonovic Vieira. Dicionário de mitologia. São Paulo: Rideel, 2005.

KOHAN, Walter. A infância da educação: o conceito devir-criança. In: KOHAN, Walter (Org.). Lugares da infância: filosofia. Rio de Janeiro: DP\&A, 2004. p.51-68.

LESKY, Albin. A tragédia grega. Tradução J. Guinsburg. São Paulo: Perspectiva, 2003. 
MOUAWAD, Wajdi. Incêndios. Tradução Angela Leite Lopes. Rio de Janeiro: Cobogó, 2013.

NIETZSCHE, Friedrich. O nascimento da tragédia ou helenismo e pessimismo. Tradução J. Guinsburg. São Paulo: Companhia das Letras, 1992.

Sobre verdade e mentira. Tradução Fernando de Moraes Barros. São Paulo: Hedra, 2008.

. Introdução à tragédia de Sófocles. Tradução Ernani Chaves. Rio de Janeiro: Jorge Zahar Ed., 2006.

POSTMAN, Neil. O desaparecimento da infância. Tradução Suzana Menescal de A. Carvalho e José Laurenio de Melo. Rio de Janeiro: Graphia Editorial, 1999.

ROMILLY, Jaqueline de. A tragédia grega. Tradução Ivo Martinazzo. Brasília: Editora Universidade de Brasília, 1998.

SÓFOCLES. Filoctetes. Tradução Trajano Vieira. São Paulo: Ed. 34, 2006. 